\title{
SOUZA, Jonathan Felix de. Inteligência espiritual: um estudo sobre o despertar de uma espiritualidade não religiosa como qualidade humana profunda nas
} organizações. 2020. Dissertação (Mestrado) - Programa de Pós-graduação em Ciências da Religião, Pontifícia Universidade Católica de Minas Gerais, Belo Horizonte, MG.*

\section{Resumo}

Nos últimos anos, o tema espiritualidade vem sendo debatido por diversas áreas do conhecimento. Com o reconhecimento de que o ser humano possui múltiplas inteligências, autores vêm construindo a fundamentação de uma inteligência que é espiritual e independe da religião. Pretende-se com esta dissertação analisar se a Inteligência Espiritual pode ser a base sobre a qual se assenta a espiritualidade como qualidade humana profunda, capaz de orientar o ser humano para a construção de sentidos de vida. Esse debate cresceu nos últimos anos dentro das empresas, pela compreensão da busca por espiritualidade nas organizações empresariais e o papel destas como articuladoras de sentido, ocupando, em alguma medida, espaços que antes eram exclusivamente das religiões. Este estudo está organizado da seguinte forma: primeiramente, conceitua-se Inteligência Espiritual e Qualidade Humana Profunda segundo seus principais formuladores. A seguir, realiza-se um comparativo dos conceitos, buscando as continuidades, rupturas e 
complementaridades, construindo, assim, uma compreensão do que seja uma Inteligência Espiritual como espiritualidade não religiosa. Por fim, averigua-se o interesse pela temática da espiritualidade nas organizações empresariais em publicações na base de dados da Associação Nacional de Pós-Graduação e Pesquisa em Administração (ANPAD). Conclui-se que o crescimento da busca por espiritualidade em instituições não religiosas confirma que vivemos um novo paradigma, em que o cultivo da espiritualidade está para além do espaço institucional religioso, e o seu cultivo não depende dele.

Palavras-chave: Ciências da Religião. Ciência da Religião Aplicada. Religião e contemporaneidade. Marià Corbí. Epistemologia axiológica. Inteligência Espiritual.

\section{Abstract}

In recent years, the topic of spirituality has been debated by several areas of knowledge. With the recognition that the human being has multiple intelligences, authors have been building the foundation of an intelligence that is spiritual and independent of religion. The aim of this dissertation is to analyze whether Spiritual Intelligence can be the basis on which spirituality is based as a profound human quality, capable of guiding human beings towards the construction of meanings of life. This debate has grown in recent years within companies, due to the understanding of the search for spirituality in business organizations and their role as articulators of meaning, occupying, to some extent, spaces that previously were exclusively of religions. This study is organized as follows: first, Spiritual Intelligence and Deep Human Quality are conceptualized according to its main formulators. Next, a comparison of the concepts is carried out, looking for continuities, ruptures and complementarities, thus building an understanding of what spiritual intelligence is as a non-religious spirituality. Finally, the interest in the theme of spirituality in business organizations is investigated by publications in the database of the National Associação Nacional de Pós-Graduação e Pesquisa em 
Administração (ANPAD). It is concluded that the growth in the search for spirituality in non-religious institutions confirms that we live in a new paradigm, in which the cultivation of spirituality is beyond the religious institutional space, and its cultivation does not depend on it.

Keywords: Religious Studies. Applied Science of Religion. Religion and contemporaneity. Marià Corbí. Axiological epistemology. Spiritual Intelligence.

\section{Resumen}

En los últimos años, el tema de la espiritualidad ha sido discutido por varias áreas del conocimiento. Con el reconocimiento de que el ser humano posee múltiples inteligencias, los autores construieron los fundamientos de una inteligencia que es espiritual e independiente de la religión. Esta disertación tiene como objetivo analizar si la Inteligencia Espiritual puede ser el fundamento en el que se basa la espiritualidad como una cualidad humana profunda, capaz de guiar al ser humano hacia la construcción de sentidos de la vida. Este debate ha crecido en los últimos años en el seno de las empresas, a través de la comprensión de la búsqueda de la espiritualidad en las organizaciones empresariales y su papel como articuladores de sentido, ocupando, en cierta medida, espacios que antes eran exclusivamente de las religiones. Este estudio está organizado de la siguiente manera: en primer lugar, conceptualizamos la Inteligencia Espiritual y la Calidad Humana Profunda de acuerdo con sus principales formuladores. A continuación se hace una comparación de los conceptos, buscando continuidades, rupturas y complementariedades, construyendo así una comprensión de lo que es una inteligencia espiritual como espiritualidad no religiosa. Finalmente, el interés por el tema de la espiritualidad en las organizaciones empresariales se verifica en las publicaciones de la base de datos de la Associação Nacional de Pós-Graduação e Pesquisa em Administração (ANPAD). Se concluye que el crecimiento de la búsqueda de la espiritualidad en las instituciones no religiosas confirma que 
vivimos un nuevo paradigma, en el que el cultivo de la espiritualidad está más allá del espacio institucional religioso, y su cultivo no depende de él.

Palabras Clave: Ciencias de la Religión. Ciencia de la Religión Aplicada. Religión y contemporaneidad. Marià Corbí. Epistemología Axiológica. Inteligencia espiritual. 